\title{
Survival of Expiratory Aerosols in a Room: Study Using a Bi-compartment and Bi-component Indoor Air Model
}

Special Issue:

Special Issue on COVID-19 Aerosol Drivers, Impacts and Mitigation (XIII)

\section{Sreekanth Bathula ${ }^{1,2}$, Srinivasan Anand ${ }^{1,3^{*}}$, Thaseem Thajudeen ${ }^{4}$, Yelia Shankaranarayana Mayya ${ }^{5}$, Probal Chaudhury ${ }^{2}$, Chaturvedi Shashank ${ }^{1,6}$}

\author{
${ }^{1}$ Homi Bhabha National Institute, Mumbai-400 094, India \\ ${ }^{2}$ Radiation Safety Systems Division, Bhabha Atomic Research Centre, Mumbai-400 085, India \\ ${ }^{3}$ Health Physics Division, Bhabha Atomic Research Centre, Mumbai-400 085, India \\ ${ }^{4}$ School of Mechanical Sciences, Indian Institute of Technology Goa, Goa-403 401, India \\ ${ }^{5}$ Department of Chemical Engineering, Indian Institute of Technology Bombay, Mumbai-400 076, \\ India \\ ${ }^{6}$ Institute for Plasma Research, Bhat Village, Gandhinagar-382428, India
}

\section{OPEN ACCESS}

Received: September 4, 2020

Revised: December 5, 2020

Accepted: January 9, 2021

\section{${ }^{*}$ Corresponding Author: \\ sanand@barc.gov.in}

\section{Publisher:}

Taiwan Association for Aerosol Research

ISSN: $1680-8584$ print

ISSN: 2071-1409 online

(c) Copyright: The Author(s).

This is an open access article distributed under the terms of the Creative Commons Attribution License (CC BY 4.0), which permits unrestricted use, distribution, and reproduction in any medium, provided the original author and source are cited.

\section{ABSTRACT}

Recent studies argue that inhalation of respiratory droplets in indoor environments is one of the significant routes of COVID-19 infection. In many cases, patients are isolated in hospitals and quarantine centers to minimize the spread. However, the rooms allocated to these patients are accessed by health care and sanitization workers a couple of times in a day. Since the expiratory activities release airborne droplets with certain viral load, there is a greater need to study the survival of these droplets in the room of a patient to control the exposure to the accessing people. A bi-compartment and bi-component numerical model is developed to study the survival of these droplets in a room, taking into consideration the deposition rates of the droplets and the ventilation rates in the room. The vital aspects related to the survival of the droplets, such as the effect of the severity of the infection, types of releases, size-dependent deposition and role of ventilation are discussed.

Keywords: COVID-19, Expiratory release, Severity of infection, Size-dependent deposition, Survival of droplets

\section{INTRODUCTION}

Even after nearly eight months since the first detection, (WHO, 2020a, b) corona virus disease (COVID-19) pandemic has been wreaking havoc to the healthcare sector and economy across the world. The pandemic has brought together researchers across multiple disciplines to understand various aspects, from the modes of transmission to finding possible cures and vaccines to the dreaded virus. Even with stringent measures, including a complete shutdown, the number of cases has been increasing at an alarming rate. Although most of the countries are in an intensive pursuit to bring out an effective vaccine or an antidote, using proven protective equipment, social distancing and quarantine are the main effective precautions followed.

It has been documented that transmission of the disease from one person to another can happen through infectious airborne droplets released from the affected person (Morawska and Cao, 2020). These droplets are released into the air when an infected person coughs or sneezes, while fine droplets can be released even through human speech with a correlation found with the loudness of the voice (Asadi et al., 2019). Even with our sustained efforts to understand the situation better, there are still many unknowns even in the modes of transmission. Transmission through expiratory droplets in an indoor environment has been touted as a significant source for 
the transmission of the viruses.

The experimental measurements (Duguid, 1946; Loudon and Roberts, 1967; Papineni and Rosenthal, 1997; Morawska et al., 2009; Johnson et al., 2011; Lindsley et al., 2012) showed that these aerosol droplets have a diameter greater than $0.1 \mu \mathrm{m}$. The droplet shrinking due to evaporation of volatile content and their trajectories following expiratory releases are investigated (Xie et al., 2007; Liu et al., 2017) and found that significant part of the droplets precipitates to the ground within 1-2 $\mathrm{m}$ range, when released in the environment. Depending on the conditions, a minor fraction could still be airborne and currently, the viral loads in the droplets are also not very well understood. However, it is quite obvious that the concentration of droplets significantly reduces due to the dilution effect apart from other processes such as deposition, coagulation etc. The lifetime of the virus on various surfaces is also an important factor in determining the spread of the disease and a few studies have been done on understanding the half-life of this virus on various surfaces (van Doremalen et al., 2020). In contrast, in an indoor environment, the droplet concentration in the air may vary drastically, as the reduction rate is controlled by many factors such as room geometry, air exchange, ventilation rate, evaporation, coagulation rate and surface deposition. Over the last few decades, there have been several studies on understanding the effects of the factors in altering the concentration of indoor air pollutants either using uniformly mixed or computational fluid dynamics models (Chen and Zhao, 2011; Buonanno et al., 2020; Feng et al., 2020). Currently, there are no studies available that describe the threshold value of infectious aerosol concentration that can cause effective transmission, and it is also likely that it might vary from person to person depending on their immunity.

Since the affected patients are isolated and kept in special rooms of hospitals and quarantine centers, studying the number concentration of infectious droplets in those facilities is very important to avoid unwanted exposure to the other people. A recent study done in two hospitals in Wuhan reported that the concentration of SARS-CoV-2 RNA in aerosols were found to be quite low in isolation wards and rooms which were well ventilated (Liu et al., 2020b). However, the concentration was found to be high in the toilet areas of the patients where the ventilation rate was quite low. More than half of the coworkers in one floor in a Korean call-center were tested positive, clearly showing the potential for transmission in indoor environments (Park et al., 2020). Other outbreaks in indoor scenarios such as in-flight transmission (Bae et al., 2020; Chen et al., 2020; Freedman and Wilder-Smith, 2020), dining at airconditioned restaurant (Lu et al., 2020), singing in confined places (Bahl et al., 2020; Miller et al., 2020) etc., raising a great concern worldwide (Morawska and Milton, 2020; World Health Organization, 2020c).

In this work, we are presenting a comprehensive investigation on the evolution of the droplet size distribution and its concentration from expiratory activities in a ventilated room, by using a bi-component, bi-compartment indoor air model, taking into account the effects of coagulation, deposition and the ventilation rates. In reality, modeling of aerosol dynamics in a ventilated room with the microphysical processes such as coagulation, deposition and resuspension following their release in the form of a turbulent jet is a complex problem for multicomponent aerosols. Hence simple indoor models are being considered which assume uniform mixing in the indoor environment with single aerosol component to avoid complexity. In the present study, a bicompartment model that account for spatial variation in gross manner and bi-component system to address the interaction of expiratory droplets with background aerosols is considered to study the virusol concentrations in a room.

\section{MODEL DEVELOPMENT}

\subsection{Problem Formulation}

The expiratory events release finite volume puffs containing aerosol droplets. These puffs are then transported and dispersed inside the room by internal mixing and ventilation. In the singlecompartment indoor model, it is assumed that the indoor pollutants/aerosols are uniformly distributed inside the whole room volume instantaneously, irrespective of the mixing and ventilation rates (Abt et al., 2000; Mosley et al., 2001; Thornburg et al., 2001; Riley et al., 2002; Asmi et al., 2004; Jamriska et al., 2003; Smolík et al., 2005; Anand et al., 2016). However, the airborne droplets may not attain a well-mixed concentration profile in the room volume under certain 
ambient conditions such as concentrated emission from sources, low mixing and ventilation rates. The well-mixed air profile assumption for low mixing rate cases also leads to the underestimation of exposure to a healthy person in the proximity of the patient and overestimation of exposure at a far distance from the patient. Hence, it is appropriate to use multi-compartment (multiplezone) indoor air model that captures the spatial variation of indoor aerosol concentration at low ventilation rates (Nazaroff and Cass, 1986, 1989; Shimada et al., 1996; Borchiellini and Fürbringer, 1999; Feustel, 1999; Schneider et al., 1999; Miller and Nazaroff, 2001; Haas et al., 2002; Gadgil et al., 2003; Lai, 2004; Hussein et al., 2005). The multi-compartment indoor air model divides the indoor space into several interactive compartments, such that the spatial variation of the particle concentration can be estimated.

In the present study, the volume of the room is divided into two compartments such that, the volume near the patient where elevated concentration levels are expected is defined as Near Field (NF) and the remaining volume of the room is defined as Far Field (FF) as shown in Fig. 1. The NF and FF volumes interact with each other through the exchange of aerosol droplets at a rate defined by their concentration differences and ventilation rate (Zhang et al., 2009; Cherrie et al., 2011; Jayjock et al., 2011; Koivisto et al., 2015; Jensen et al., 2018; Ribalta et al., 2019; Cherrie et al., 2020). The bi-compartmental approach in the present study considers only two discrete concentrations at NF and FF, and hence, it may not be able to capture the continuous spatial variation of particulate concentration in the entire volume. The rate of change of aerosol droplets in a given volume (NF or FF) can be written as,

$$
\frac{d N_{k}}{d t}=S+\left.\frac{d N_{k}}{d t}\right|_{\text {Evaporation }}+\left.\frac{d N_{k}}{d t}\right|_{\text {Ventilation }}+\left.\frac{d N_{k}}{d t}\right|_{\text {Exchange }}+\left.\frac{d N_{k}}{d t}\right|_{\text {Deposition }}+\left.\frac{d N_{k}}{d t}\right|_{\text {Coagulation }}
$$

where, $N_{k}$ is the number concentration of the droplets of size $k$ in either NF or FF $\left(\# \mathrm{~m}^{-3}\right)$ and $S$ is the source emission rate $\left(\# \mathrm{~m}^{-3} \mathrm{~s}^{-1}\right)$. The individual terms in RHS of Eq. (1) are explained in the following sections.

\subsection{Evaporation}

The expiratory droplets consist mainly of water, $\mathrm{NaCl}, \mathrm{KCl}$, organic matter such as glycoprotein, and potential pathogens, where the volume percentage of insoluble solid materials is $\sim 1.8-3 \%$ (Duguid, 1946; Liu et al., 2017). At a typical indoor room temperature of $25^{\circ} \mathrm{C}$, the equilibrium diameter of the droplet becomes $25-40 \%$ of the initial droplet diameter due to evaporation process (Liu et al., 2017). The evaporation rate and equilibrium diameter depend on the temperature, humidity, and solid residues in the droplets. Evaporation is a rapid process and is not explicitly modeled in this study. Hence, we consider that the dry droplet nuclei diameter reduces to $32 \%$ (an average value) of the original diameter of the wet droplet owing to evaporation.

\section{Out door}

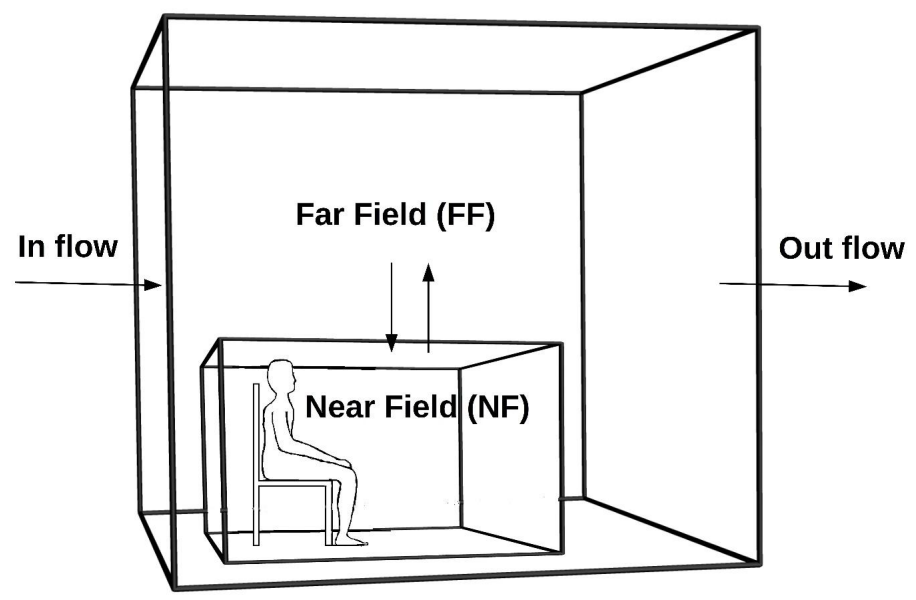

Fig. 1. Schematic representation of a room. 


\subsection{Ventilation}

The background aerosol from the outdoor environment enters the FF volume of the room through ventilation. The rate of change of number concentration of particles in the FF volume $\left(N_{F F, k}\right)$ due to ventilation can be written as:

$$
\left.\frac{d N_{F F . k}}{d t}\right|_{\text {Ventilation }}=-\lambda_{v} N_{F F, k}
$$

where, $\lambda_{v}$ is the ventilation rate $\left(\mathrm{h}^{-1}\right)$. In a naturally ventilated room, the ventilation rate may vary from $\sim 10^{-3} \mathrm{~h}^{-1}$ for a poorly ventilated room to $\sim 5 \mathrm{~h}^{-1}$ for highly ventilated (Anand et al., 2016).

\subsection{Air-exchange}

The rate of change of number concentration of the aerosol droplets due to air-exchange between the NF and FF compartments are estimated as (Hussein et al., 2005; Hussein and Kulmala, 2010; Jayjock et al., 2011; Koivisto et al., 2015; Jensen et al., 2018; Ribalta et al., 2019):

$$
\begin{aligned}
& \left.\frac{d N_{N F . k}}{d t}\right|_{\text {Exchange }}=\frac{1}{V_{N F}}\left(Q_{F F, N F} N_{F F, k}-Q_{N F, F F} N_{N F, k}\right) \\
& \left.\frac{d N_{F F . k}}{d t}\right|_{\text {Exchange }}=\frac{1}{V_{F F}}\left(Q_{N F, F F} N_{N F, k}-Q_{F F, N F} N_{F F, k}\right)
\end{aligned}
$$

where, $Q_{N F, F F}$ and $Q_{F F, N F}$ are the flow rates $\left(\mathrm{m}^{3} \mathrm{~s}^{-1}\right)$ from NF to FF and from FF to NF, respectively. $V_{N F}$ and $V_{F F}$ are the volumes $\left(\mathrm{m}^{3}\right)$ of the NF and FF compartments.

Under natural convection, the air entering the NF will be equal to air leaving the NF, else NF will be pressurized or evacuated of air. Hence, flow rates $Q_{N F, F F}$ and $Q_{F F, N F}$ can be written as (Zhang et al., 2009; Hussein and Kulmala, 2010; Cherrie et al., 2011; Jayjock et al., 2011; Jensen et al., 2018; Ribalta et al., 2019; Cherrie et al., 2020):

$Q_{N F, F F}=Q_{F F, N F}$

Since there are no other paths of air exchange processes existing between the NF and FF except the natural ventilation, the flow rates $Q_{N F, F F}$ and $Q_{F F, N F}$ can be simplified as (Hussein and Kulmala, 2010; Jensen et al., 2018):

$Q_{N F, F F}=Q_{F F, N F}=\lambda_{v} V_{R o o m}$

where, $V_{\text {Room }}$ is the volume $\left(\mathrm{m}^{3}\right)$ of the whole room.

\subsection{Deposition}

The rate of change of number concentration due to deposition in NF and FF can be written as:

$$
\begin{aligned}
& \left.\frac{d N_{N F . k}}{d t}\right|_{\text {Deposition }}=-\lambda_{N F, k} N_{N F, k} \\
& \left.\frac{d N_{F F . k}}{d t}\right|_{\text {Deposition }}=-\lambda_{F F, k} N_{F F . k}
\end{aligned}
$$

where, $\lambda_{N F, k}$ and $\lambda_{F F, k}$ are the deposition rates of droplets of size $k$ in NF and FF, respectively. The deposition rates on the indoor surfaces as a result of Brownian diffusion, eddy diffusion and gravitational settling are obtained using Lai and Nazaroff model (2000). In a room, the droplets 
can deposit on all 6 surfaces (four walls, ceiling and floor), and the resulting deposition rate in FF can be written as

$$
\lambda_{F F, k}=\frac{1}{V_{F F}} \sum_{j=1}^{6} A_{j, F F} v_{d, j, k}
$$

where, $A_{j, F F}$ is the area $\left(\mathrm{m}^{2}\right)$ of surface $j$ in the FF and $v_{d, j, k}$ is deposition velocity $\left(\mathrm{m} \mathrm{s}^{-1}\right)$ of the droplet of size $k$ on surface $j$. Similarly, the deposition rate in NF can be written as,

$$
\lambda_{N F, k}=\frac{1}{V_{N F}} A_{\text {ground }, N F} v_{d, k}
$$

where, $A_{\text {ground,NF }}$ is area $\left(\mathrm{m}^{2}\right)$ of the ground surface in NF and $v_{d, k}$ is deposition velocity ( $\mathrm{m} \mathrm{s}^{-1}$ ) of the droplet of size $k$ on the ground surface. The deposition rate as a function of the particle diameter for the numerical calculations is calculated using Lai and Nazaroff model (2000), and results for a given friction velocity $\left(u^{*}=1 \mathrm{~cm} \mathrm{~s}^{-1}\right)$ (Anand et al., 2016) are shown in Fig. 2.

\subsection{Coagulation}

The coagulation process is significant if the aerosol number concentration is higher than $\sim 10^{10} \mathrm{\#} \mathrm{m}^{-3}$ (Hussein et al., 2009a, b; Hussein and Kulmala, 2010; Anand et al., 2016). In the present study, the number concentration of expiratory droplets of this order is highly unlikely, and hence the self-coagulation is insignificant. The number concentration of background aerosols in the indoor environment may reach $10^{10}-10^{11} \mathrm{\#} \mathrm{m}^{-3}$ under certain conditions (Hussein et al., 2006; Dhaniyala et al., 2011), and hetero-coagulation between aerosol droplets and background aerosol is possible. Although self and hetero-coagulation may not affect the population of the aerosol droplets noticeably, it captured attention in recent studies (Feng et al., 2020). To address this issue, the effect of coagulation is studied using a bi-component aerosol coagulation mode (Annexure A) (Jacobson et al., 1994) for the case of a single sneeze release, where high number concentration of droplets is observed.

\subsection{Input Parameters}

\subsubsection{Room dimension}

The most common scenario that a healthy person gets exposed to airborne droplets is by either entering into a patient room or if the patient visits the room for a brief period of time. Room dimension and volume play a vital role in dilution and deposition of the particles in an indoor

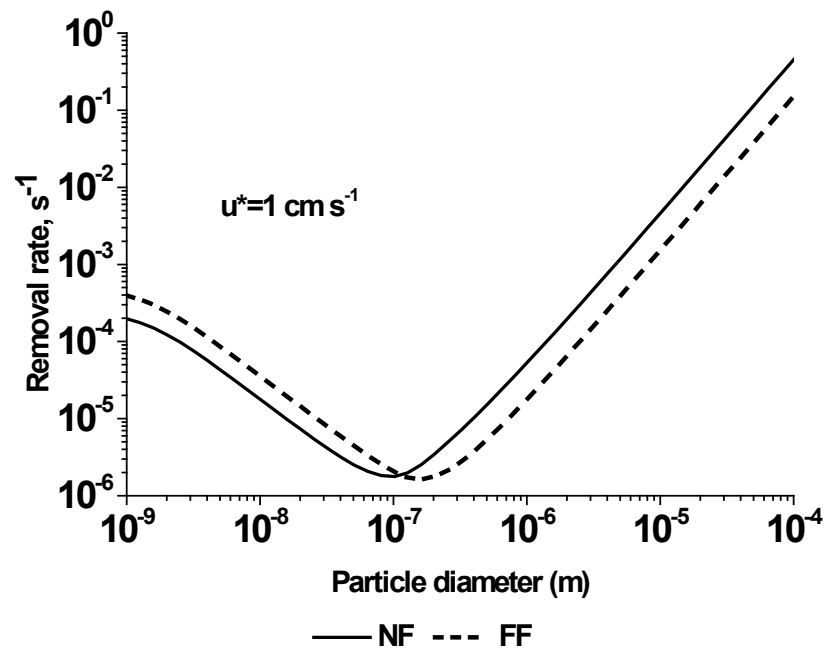

Fig. 2. Particle size-dependent removal rate in NF (volume $\left.=2 \mathrm{~m}^{3}\right)$ and $F F\left(\right.$ volume $\left.=25 \mathrm{~m}^{3}\right)$ of the room (volume $27 \mathrm{~m}^{3}$ ). 
environment. Typical dimensions of a bedroom or isolation room in a hospital for a single person is $\sim 3 \mathrm{~m} \times 3 \mathrm{~m} \times 3 \mathrm{~m}(\mathrm{I} \times \mathrm{w} \times \mathrm{h})$. Various studies estimate the ballistic range of expiratory droplets from cough and sneeze up to 1-2 m (Xie et al., 2007; Bourouiba et al., 2014; Liu et al., 2017). Hence, the volume of NF is considered as $2 \mathrm{~m}^{3}$ cuboid with dimensions $2 \mathrm{~m} \times 1 \mathrm{~m} \times 1 \mathrm{~m} \mathrm{(I \times w \times}$ h); the rest of the room volume $\left(25 \mathrm{~m}^{3}\right)$ is considered as FF volume (Fig. 1).

\subsection{Expiratory Releases}

Coughing, Sneezing, Speaking and Exhalation are the prominent routes by which aerosols and droplets are expelled, thereby increasing the possibility of spreading infectious diseases. Exhalation releases the lowest number of particles compared to others, but it is a continuous and more important route to the study of transmission from an asymptomatic patient. Although speaking releases fewer droplets compared to sneezing and coughing, the duration could extend from a few seconds to minutes, thereby making it a possible source of exposure. Despite numerous studies on the cough droplet size distribution (Duguid, 1946; Loudon and Roberts, 1967; Papineni and Rosenthal, 1997; Morawska et al., 2009; Lindsley et al., 2010; Johnson et al., 2011; Lindsley et al., 2012), there is significant variation in the published data. We consider the classical study of Duguid (1946) for cough and sneeze releases (Table 1), and Morawska et al. (2009) for the expiratory events such as speaking and breathing (Table 2), as model data in this study. The average volume flow rates for breathing and speaking events are considered as $0.49 \mathrm{~m}^{3} \mathrm{~h}^{-1}$ and $1.38 \mathrm{~m}^{3} \mathrm{~h}^{-1}$ respectively.

\subsection{Virus Carrying Droplets in Expiratory Releases}

In a recent study by Stadnytskyi et al. (2020) it has been shown that the probability of viral load ina given droplet increases with its diameter and the actual viral load in the oral fluid, indicating that not all the expiratory aerosol droplets carry viral copies. This behavior is explained using the Poisson probability theory and experiments (Duguid, 1946; Fernandez et al., 2019; Anand and Mayya, 2020). The probability that a droplet of diameter $d$ carrying at least one virus (RNA) copy can be written as, $P_{v}=1-P_{0}=1-e^{-\mu}$, where $P_{0}$ is the probability for droplet (diameter, d) not carrying any virus copy, $\mu$ is recognized as the "propensity parameter" for the formation of virus-laden particles defined as $\mu=\frac{\pi}{6} d^{3} C_{v}, C_{v}$ be the concentration (RNA copies $\mathrm{mL}^{-1}$ ) of viral copies in the oral fluid of the patient. The virus carrying droplets are termed as 'virusol droplets' to distinguish it from droplet which is not carrying virus copy (clean droplets). Hence, the total volume concentration of the virusol droplets of diameter $d$ can be written as

$V_{d, v}=V_{d}\left[1-e^{-\frac{\pi}{6} 3^{3} c_{v}}\right]$

where, $V_{d}\left(\mathrm{~m}^{3} \mathrm{~m}^{-3}\right)$ is the total volume concentration of the expiratory droplets of diameter $d$. The number concentration $\left(\# \mathrm{~m}^{-3}\right.$ ) of virusol droplets of diameter $d$ can also be written as

$N_{d, v}=V_{d, v} /\left(\frac{\pi}{6} d^{3}\right)$

In the present study, we have applied this correction to estimate the virusol (virus laden droplets) concentration and its size distribution.

Table 1. Lognormal fit of Duguid's data (Nicas et al., 2005).

\begin{tabular}{lll}
\hline Expiratory event & Total number of droplets & Size distribution parameters \\
\hline Cough & $5 \times 10^{3}$ & $\mathrm{GM}^{\dagger} 14 \mu \mathrm{m}$ and GSD ${ }^{\ddagger} 2.6$ \\
Sneeze & $1 \times 10^{6}$ & $\mathrm{GM} 8.1 \mu \mathrm{m}$ and GSD 2.3 \\
\hline
\end{tabular}

${ }^{\dagger} \mathrm{GM}$ - geometric mean; ${ }^{\ddagger} \mathrm{GSD}$ - geometric standard deviation. 
Table 2. Size distribution of expiratory droplets (Morawska et al., 2009).

\begin{tabular}{lll}
\hline Expiratory event & Particle size, $\mu \mathrm{m}$ & Number concentration, \# $\mathrm{m}^{-3}$ \\
\hline Speaking & 0.8 & $7.5 \times 10^{5}$ \\
& 1.8 & $1.4 \times 10^{5}$ \\
& 3.5 & $1.4 \times 10^{5}$ \\
Breathing & 5.5 & $5.9 \times 10^{4}$ \\
& 0.8 & $8.4 \times 10^{4}$ \\
& 1.8 & $9 \times 10^{3}$ \\
& 3.5 & $3 \times 10^{3}$ \\
& 5.5 & $2 \times 10^{3}$ \\
\hline
\end{tabular}
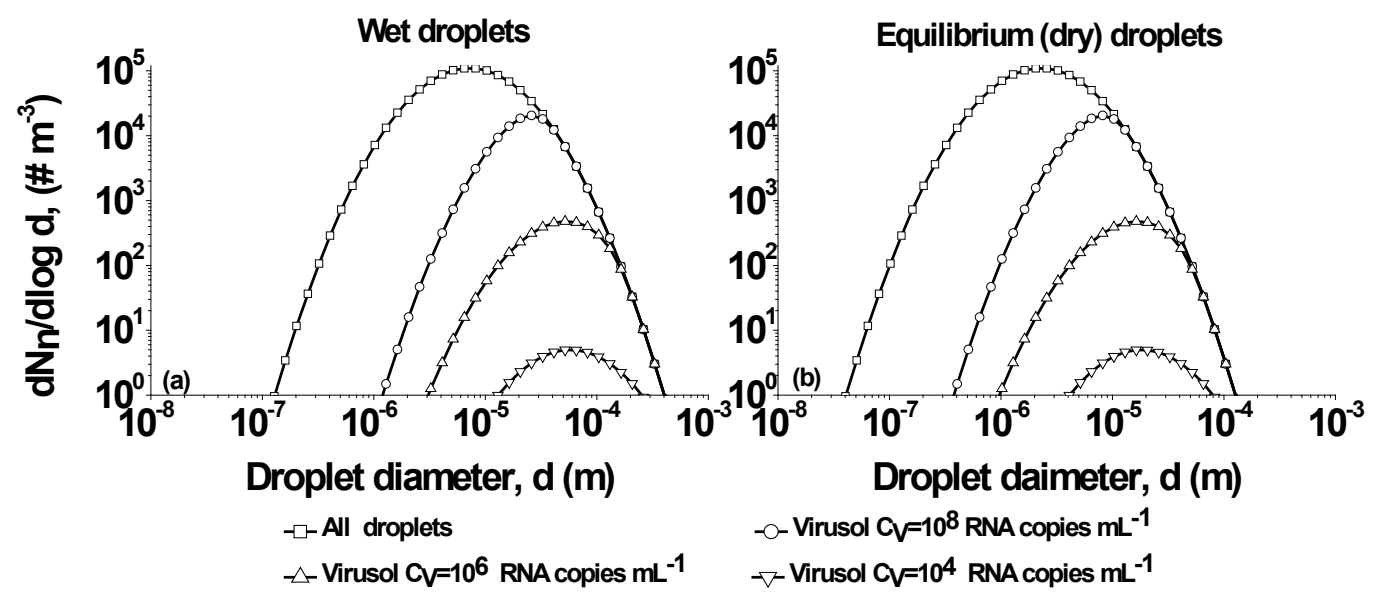

Fig. 3. Virusol droplet number distributions for different viral loads (a) wet virusol droplets and (b) equilibrium (dry) virusol droplets.

\subsection{Virusol Size Distribution}

A typical size distribution of sneeze is considered here to demonstrate the evaluation of virusol size distribution. Two main input parameters are required to estimate the virusol size distribution, viz., droplet size distribution and viral load in the oral fluid (Eq. (10)). The total number of wet droplets released in a single sneeze is $\sim 10^{6}$, and the lognormal fit of this Duguid's sneeze data gives a CMD of $8.1 \mu \mathrm{m}$ with GSD = 2.3 (Nicas et al., 2005). Depending on the severity of infection, mild to moderately infected cases may have viral load less than $10^{6} \mathrm{RNA}$ copies $\mathrm{mL}^{-1}$ and severe cases tend to have a viral load greater than $10^{6}$ RNA copies $\mathrm{mL}^{-1}$ (Liu et al., 2020a). With these parameters, the number size distribution of virusol droplets for three different viral loads $\left(10^{8}\right.$, $10^{6}$ and $10^{4}$ RNA copies $\mathrm{mL}^{-1}$ ) are computed using Eq. (11) and the results are shown in Fig. 3(a).

Fig. 3(b) displays virusol droplet size distribution of dry droplets after applying the evaporation correction to wet virusol droplet size distribution. From these figures (Figs. 3(a) and 3(b)), it is clear that, the probability of carrying a virus copy in the aerosol droplets increases with droplet size and viral load. In the case of a low viral load of $10^{4}$ RNA copies $\mathrm{mL}^{-1}$, the probability for a wet droplet smaller than $10 \mu \mathrm{m}$ to carry a virus copy is extremely small, and only $\sim 45$ out of $10^{6}$ droplets are expected to carry virus copies and hence can be categorized as virusol droplets. When the viral load is higher $\left(10^{8}\right.$ RNA copies $\left.\mathrm{mL}^{-1}\right)$, the probability of viral load in smaller droplets increases. In this case, the lower cut-off diameter is around $1 \mu \mathrm{m}$ and hence total virusol droplet number is $\sim 10^{5}$ (out of $10^{6}$ ). After applying evaporation correction, the lower cut-off diameters of dry virusol droplets are $\sim 3 \mu \mathrm{m}$ and $0.3 \mu \mathrm{m}$ for viral loads of $10^{4}$ and $10^{8}$ RNA copies $\mathrm{mL}^{-1}$, respectively (Fig. 3(b)). These size distribution data are used in the present numerical simulations.

\section{RESULTS AND DISCUSSION}

The size distribution of the droplets from each type of expiratory activity is different and hence 
virusol droplet size distribution is also expected to be different. Breathing and speaking produce small-sized particles (diameter range $0.8 \mu \mathrm{m}-5.5 \mu \mathrm{m}$ ) (Morawska et al., 2009) and cough produces a wide range of particle sizes and with large particles as big as $2 \mathrm{~mm}$ in diameter (Duguid, 1946). Sneeze release is the most significant among other expiratory releases, with the highest number of droplets with wider size distribution. As discussed earlier, the population of the virusol droplets from an expiratory activity in a given room depends on release mode (ex: single, continuous and intermittent) as well as the transport, dispersion properties of indoor air (ex: mixing rate, ventilation rate) and dimensions of the room. The simulation results of the virusol droplets from expiratory releases are discussed in the following section.

\subsection{Virusol Effect}

The importance of virus-laden droplets (virusols) compared to normal droplets which do not account for the viral contamination, is studied using a particular case of single sneeze that releases $\sim 10^{6}$ number of droplets and viral load of $10^{8}$ RNA copies $\mathrm{mL}^{-1}$ in a poorly ventilated room $\left(\lambda_{v}=10^{-3} \mathrm{~h}^{-1}\right)$ of dimensions $3 \mathrm{~m} \times 3 \mathrm{~m} \times 3 \mathrm{~m}$. The temporal variation of concentrations of clean and virusol droplets are shown in Fig. 4. The initial difference in the number concentration of droplets is due to the difference in the total number of clean and virusol droplets estimated using Eqs. (10) and (11). The results show that the maximum concentration in FF $\left(\sim 5 \# \mathrm{~m}^{-3}\right)$ is very low compared to that of NF $\left(\sim 6 \times 10^{4} \mathrm{\#} \mathrm{m}^{-3}\right)$, i.e., most of the released virusol droplets are contained in the NF, due to very low ventilation $\left(\lambda_{v}=10^{-3} \mathrm{~h}^{-1}\right)$. The number concentration of the clean/virusol droplets in NF decreases continuously over time due to the effects of deposition and ventilation. It can be seen from the Fig. 4 that the rate of decrease of total number concentration is different for clean and virusol droplets. Also, there is a large difference in the FF concentration of clean and virusol droplets. This is mainly due to the difference in their size distribution, which impacts the deposition and survival of airborne droplets, which is confirmed from the evolution of their size spectra. Simulation results also show that the virusol droplet concentration is two orders of magnitude lesser compared to the clean droplets.

\subsection{Ventilation Effect}

Since both ventilation and deposition play significant roles in reducing the survival time of airborne virusol droplets, it is important to understand their competitive role in removing the virusol droplets. For single sneeze release, the virusol droplets concentrations inside a room are simulated for different levels of ventilation, i.e., poorly ventilated room $\left(10^{-3} \mathrm{~h}^{-1}\right)$, moderately ventilated room $\left(0.5 \mathrm{~h}^{-1}\right)$, and well-ventilated room $\left(>1 \mathrm{~h}^{-1}\right)$. The removal percentage of deposition

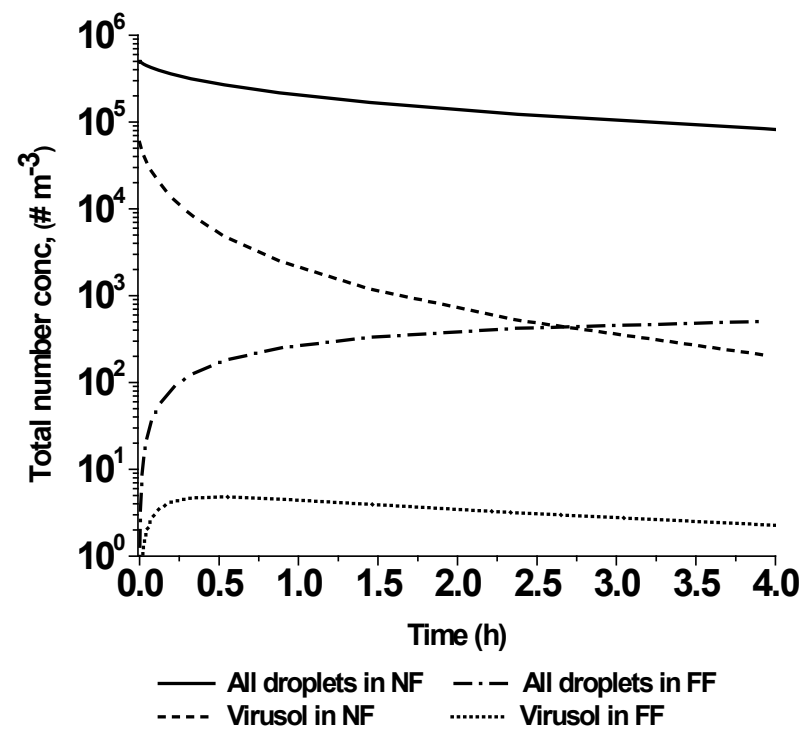

Fig. 4. Temporal variation of total number concentration of all droplets and virusol droplets in NF and FF $\left(C_{v}=10^{8}\right.$ RNA copies $\mathrm{mL}^{-1}$ and $\left.\lambda_{v}=10^{-3} \mathrm{~h}^{-1}\right)$. 

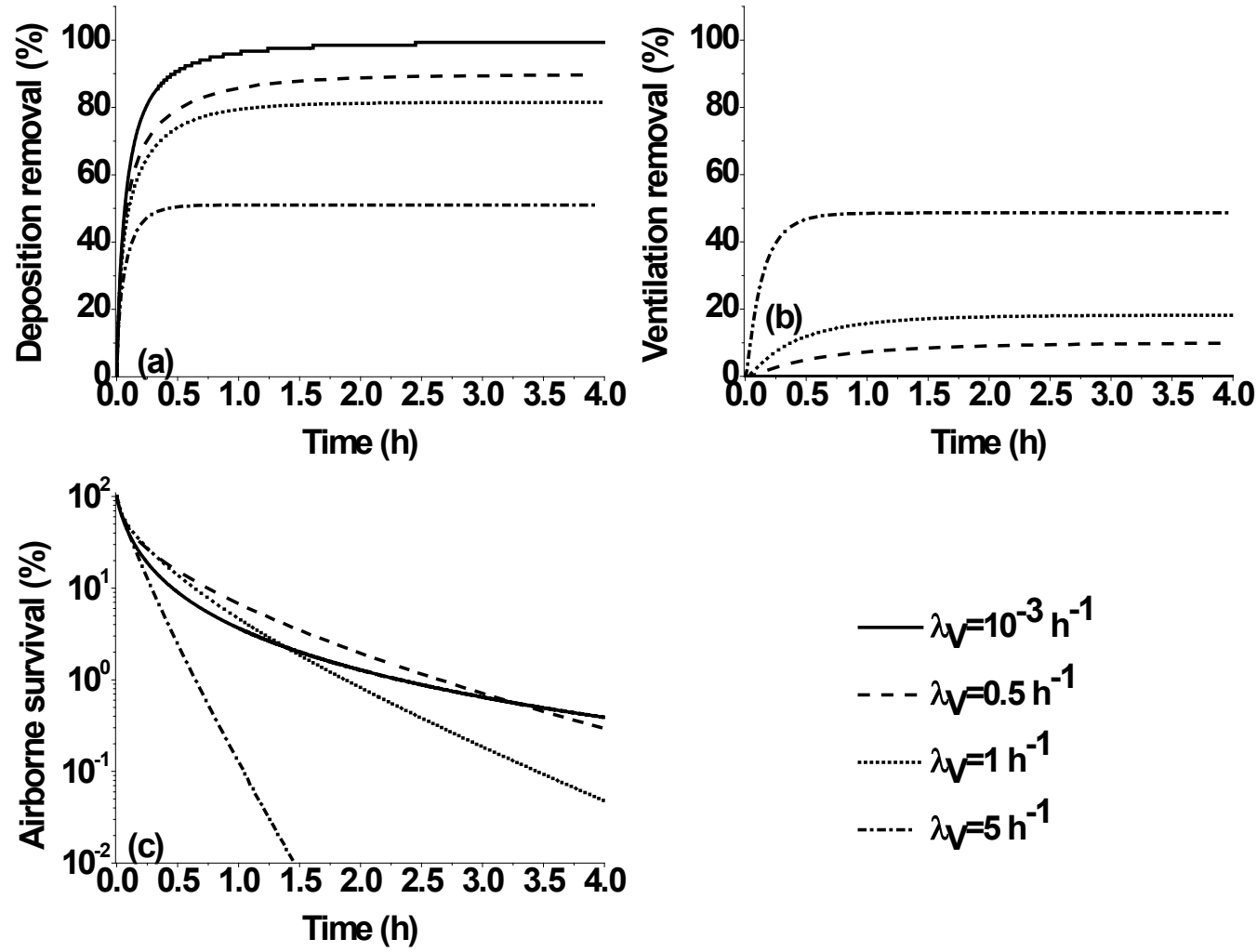

Fig. 5. Temporal variation of (a) deposition removal (\%), (b) ventilation removal (\%) and (c) airborne survival (\%), of virusol droplets $\left(C_{v}=10^{8}\right.$ RNA copiesmL $\left.{ }^{-1}\right)$ in the whole room (since ventilation removal for $\lambda_{v}=10^{-3} \mathrm{~h}^{-1}$ is very small, and it is not visible in the plot).

and ventilation processes for different ventilation levels are shown in Figs. 5(a) and 5(b). The survival percentage of virusols is presented in Fig. 5(c). For a small ventilation rate, most of the virusol droplets are confined to NF, and are deposited in the NF itself. In contrast, for higher ventilation rates, the virusol droplets in the NF are transported to the FF due to an increased airflow rate. When the ventilation rate is increased from $10^{-3} \mathrm{~h}^{-1}$ to $5 \mathrm{~h}^{-1}$, the total deposition percentage reduces from $99 \%$ to $51 \%$ (Fig. 5(a)), and the NF deposition percentage reduces to $22 \%$ from $99 \%$. Furthermore, the virusol droplets reaching the FF are diluted due to the larger volume and results in a comparatively lower deposition rate and a larger survival fraction. When the ventilation rate increases, the survival percentage of virusol droplets increases initially, and then it reduces as expected. The initial increase in the survival is due to the reason that slight increase in the ventilation rate results in the transport of droplets from NF to FF region, evading the deposition in the NF region and hence, more airborne concentration compared to the case of the very low ventilation rate $\left(10^{-3} \mathrm{~h}^{-1}\right)$. The results also show that it takes approximately 45 and 15 minutes to reduce the initial airborne fraction to $10 \%$ for ventilation rates $1 \mathrm{~h}^{-1}$ and $5 \mathrm{~h}^{-1}$, respectively. Though higher ventilation rates may cause a significant reduction in the survival fractions of the virusol droplets in a room, ensuring high ventilation rates is not a trivial task. This study of the effect of ventilation rate is especially useful in estimating the optimum ventilation rate required for a better reduction in the survival fraction of airborne virusol droplets.

\subsection{Coagulation Effect}

In the present study, a bi-component model, as described in Annexure A, is used to address the effect of the hetero-coagulation process between background aerosols (number concentration $=10^{10} \mathrm{\#} \mathrm{m}^{-3}, \mathrm{CMD}=100 \mathrm{~nm}$ and GSD = 1.6) (Hussein et al., 2006; Dhaniyala et al., 2011) and cough expiratory droplets (number concentration $\sim 10^{3}-10^{5} \# \mathrm{~m}^{-3}$ ). The effect of self-coagulation is insignificant since the total number concentration of expiratory droplets (maximum $10^{6} \# \mathrm{~m}^{-3}$ for sneezing) is very low. To study the effect of heterogenous coagulation, the ventilation rate is 

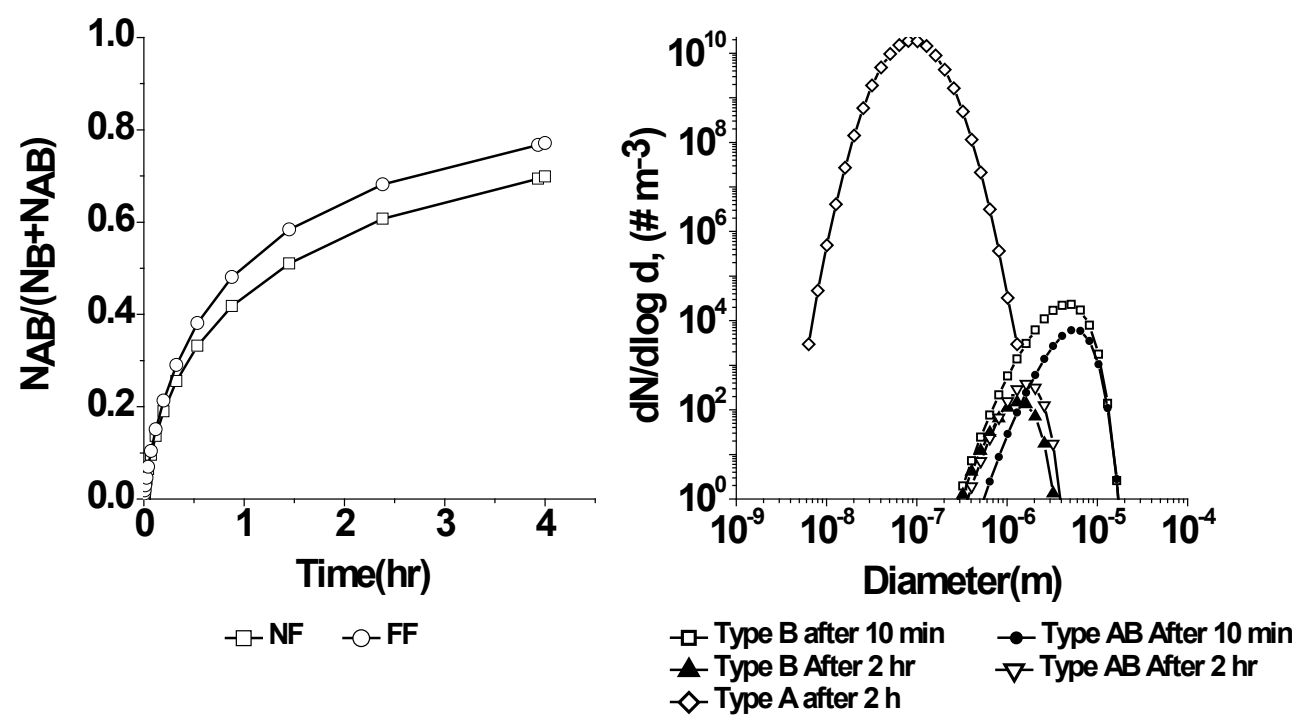

Fig. 6. Temporal evolution of (a) number fraction of virusol droplets in NF and FF regions, and (b) number size distribution of Type $B$ and $A B$ virusol droplets at different times in NF (Type $A$ is pure background particle, Type $B$ is pure virusol droplet and Type $A B$ is a combination of both Type A and Type B).

reduced to $10^{-3} \mathrm{~h}^{-1}$ to suppress the effect of ventilation removal process but surface deposition is included. In order to distinguish expiratory droplets from background aerosols in the numerical model, background aerosols and expiratory aerosol droplets are termed as component Type $A$ and component Type $B$, respectively. Whereas, the droplet of Type $A B$ is a combination of both Type $A$ and Type $B$ droplets. The simulation results for sneeze release show that Type $A B$ virusol droplets form $\sim 19 \%$ of the total virusol droplets within the first $10 \mathrm{~min}$ and it slowly increases to $\sim 70 \%$ at $4 \mathrm{~h}$ due to hetero-coagulation between Type A, B and AB (Fig. 6(a)). The percentage of Type $A B$ virusol droplets in FF are higher compared to NF because more number of Type $B$ particles in NF are converting into Type $A B$ and hence more number of Type $A B$ particles are drifted to FF. Thus, the population of Type $A B$ increases more in FF compared to NF. The number-size distribution of Type $B$ and $A B$ droplets are not different (Fig. $6(\mathrm{~b})$ ). The results show that there is no significant change in the total number concentration of virusol droplets and its size distribution. However, hetero-coagulation plays role in coagulating virusol droplets with background aerosols. The effect of hetero-coagulation and surface deposition together makes significant difference in the size distribution of pure virusol droplets (Type B) and background attached virusol droplet (Type AB).

\subsection{Scenario of a COVID-19 Patient in a Room}

Though the symptoms of the severity are expected to increase with an increase in the viral load, no empirical correlation has been found between them. There is a general consensus that a significant fraction ( $81 \%$ ) of the patients are mild to moderate cases, i.e., patients having viral load $<10^{6}$ RNA copies $\mathrm{mL}^{-1}$ (Chua et al., 2020). Fig. 2 shows that the virusol concentration for this viral load is low and hence, we consider the viral load corresponding to the severe case $\left(10^{8}\right.$ RNA copies $\mathrm{mL}^{-1}$ ) in this study. Each of the common expiratory activities of an infected person is different in the quantity of droplets released and mode of release, i.e., breathing is periodic (with very small time interval), whereas speaking, coughing and sneezing are completely random. To simulate the temporal release rate of expiratory droplets into the room, the random occurrences of these release activities need to be properly defined. In this study, the release modes of expiratory activities are assumed as continuous breathing, speaking in every half an hour for oneminute time period, coughing once in every five minutes and sneezing once in every hour.

Combination of these expiratory activities can create various scenarios due to the presence of an infected patient with a viral load of $10^{8}$ RNA copies $\mathrm{mL}^{-1}$ in the room of volume $27 \mathrm{~m}^{3}$ with a ventilation rate of $1 \mathrm{~h}^{-1}$. In the present study, we consider four different scenarios such as Scenario 1: release by exhalation of breathing only $\left(\sim 0.11\right.$ virusol droplets $\left.\mathrm{s}^{-1}\right)$, Scenario 2 : breathing and 
speaking ( $\sim 9.5$ virusol droplets $\mathrm{s}^{-1}$ ), Scenario 3: breathing, speaking and coughing (1450 virusol droplets per event), and Scenario 4: breathing, speaking, coughing and sneezing $\left(1.2 \times 10^{5}\right.$ virusol droplets per event). The modeling results of the temporal evolution of virusol droplets from these scenarios are shown in Fig. 7.

The simulation results show that simple breathing (Scenario 1 ) develops up to $\sim 18$ virusol droplets $\mathrm{m}^{-3}$ in NF and up to 7 virusol droplets $\mathrm{m}^{-3}$ in FF (Fig. 7(a)). When speaking and breathing considered together (Fig. 7(b), Scenario 2), the NF concentration varies in the range of 30-280 virusol droplets $\mathrm{m}^{-3}$ while the concentration in the FF varies from $18-29$ virusol droplets $\mathrm{m}^{-3}$. The variation is due to the release of more number of droplets during speaking activity. In the Scenario 3, the NF concentration range increases to $170-900$ virusol droplets $\mathrm{m}^{-3}$ while in the FF it is 90 virusol droplets $\mathrm{m}^{-3}$ (Fig. 7(c)); large variation in the number concentration is due to cough event which releases a large number of droplets, but they settle down rapidly in the NF owing to their size. When all the expiratory events are combined together as shown in Scenario 4, NF concentration increases to $\sim 6 \times 10^{4}$ virusol droplets $\mathrm{m}^{-3}$ mainly due to the sneeze droplets and $\mathrm{FF}$ concentration varies in the range of 1000-2500 virusol droplets $\mathrm{m}^{-3}$ (Fig. 7(d)). Since the virusol droplets of sneeze are smaller than cough droplets, a large number of droplets survive in this scenario and relatively a constant value $\left(\sim 10^{3}\right.$ virusol droplets $\left.\mathrm{m}^{-3}\right)$ is attained in this case at NF as well as FF regions. However, it is important to note that these calculations are carried out without considering any physical protective equipment worn by the infected patient. By multiplying the volume of virusol droplets with the viral load and probability of viral contamination, the viral concentration in the room environment can be estimated. The numerical results show that there is a constant virusol droplet concentration exists in a room where the expiratory activities of a
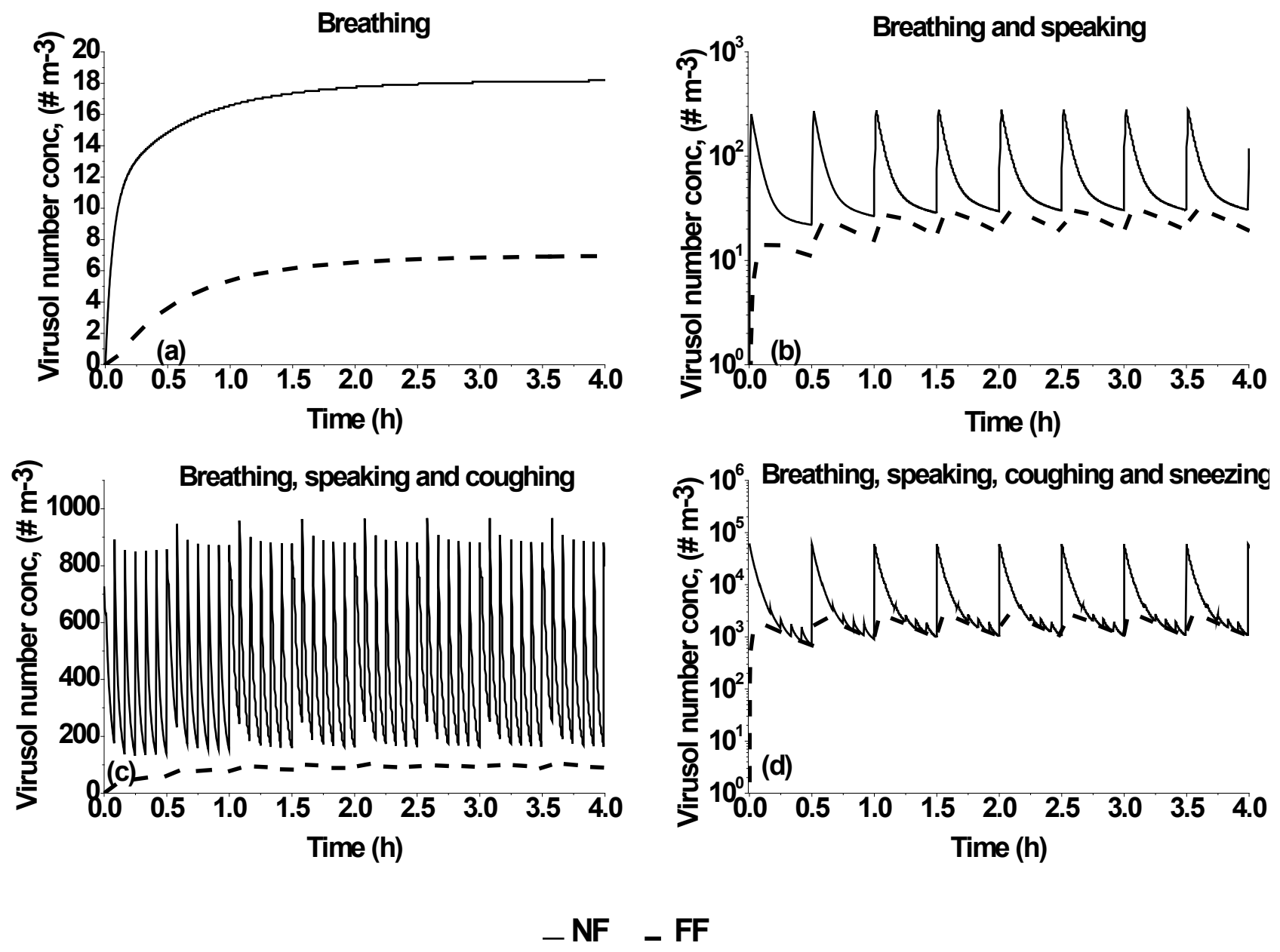

Fig. 7. Temporal variation of virusol droplets in the room for various scenarios (a. Scenario-1, b. Scenario-2, c. Scenario-3, d. Scenario-4). 


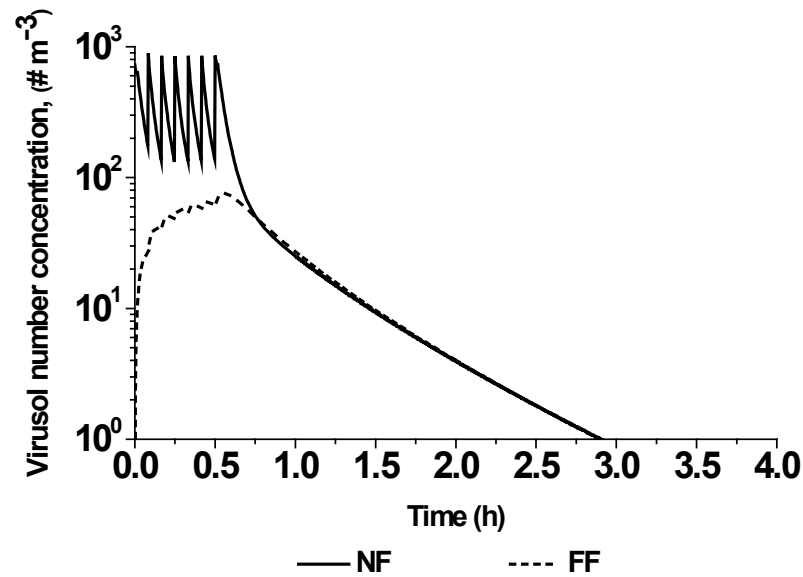

Fig. 8. Temporal variation of virusol droplets in a room due to half an hour visit of a severe symptomatic patient.

severe symptomatic patient $\left(10^{8}\right.$ RNA copies $\left.\mathrm{mL}^{-1}\right)$ takes place. In the case of mild to moderate severity cases $\left(<10^{6}\right.$ RNA copies $\left.\mathrm{mL}^{-1}\right)$, the virusol concentration will be much lower in the room environment. Another interesting scenario, in which a severe symptomatic patient visits a room for half an hour period and he only coughs during that period, as described in Scenarios 3 and 4. The results are plotted in Fig. 8. The results show that it takes around $2.5 \mathrm{~h}$ for the number concentration of virusol droplets to become negligible.

\section{CONCLUSIONS}

A numerical model is developed to study the survival of airborne expiratory droplets released in a room by a COVID-19 patient. The model addresses the important aspects such as nonuniform variation of number concentrations in different compartments, severity of infection, size-dependent deposition of particles and effect of ventilation rate. The simulation results showed that a significant difference in the concentrations of virusol droplets is observed near- and far-field volumes from the patient in the case of short-term intermittent expiratory releases. Furthermore, it is observed that the airborne concentration of virusols widely varies from $\sim 6 \mathrm{~m}^{-3}$ to $10^{3} \# \mathrm{~m}^{-3}$ depending on the expiratory release processes from an infected person with a high viral load of $10^{8}$ RNA copies $\mathrm{mL}^{-1}$ in a typical room environment. The study revealed that more submicronsized virusol droplet generation increases with the severity of the infection; these submicronsized particles have higher survival percentages for an extended period following the release. Compared to ventilation removal process, the size-dependent deposition is relatively more effective in the removal of virusol droplets. The developed model is easily customizable for rooms of given dimension, and the results will help in implementing the protective measures to control the spread of the disease.

\section{SUPPLEMENTARY MATERIAL}

Supplementary data associated with this article can be found in the online version at https://doi.org/10.4209/aaqr.200547

\section{REFERENCES}

Abt, E., Suh, H.H., Catalano, P., Koutrakis, P. (2000). Relative contribution of outdoor and indoor particle sources to indoor concentrations. Environ. Sci. Technol. 34, 3579-3587. https://doi.org/ 10.1021/es990348y

Anand, S., Mayya, Y.S. (2020). Size distribution of virus laden droplets from expiratory ejecta of infected subjects (preprint). In Review. https://doi.org/10.21203/rs.3.rs-32798/v1 
Anand, S., Sreekanth, B., Mayya, Y.S. (2016). Ventilation dependence of concentration metrics of Ultra-fine Particles in a coagulating household smoke. Inhalation Toxicol. 28, 39-47. https://doi.org/10.3109/08958378.2015.1130759

Asadi, S., Wexler, A.S., Cappa, C.D., Barreda, S., Bouvier, N.M., Ristenpart, W.D. (2019). Aerosol emission and superemission during human speech increase with voice loudness. Sci. Rep. 9, 2348. https://doi.org/10.1038/s41598-019-38808-z

Asmi, A.J., Pirjola, L.H., Kulmala, M. (2004). A sectional aerosol model for submicron particles in indoor air. Scand. J. Work. Environ. Health 30, 63-72.

Bae, S.H., Shin, H., Koo, H.Y., Lee, S.W., Yang, J.M., Yon, D.K. (2020). Asymptomatic transmission of SARS-CoV-2 on evacuation flight. Emerg. Infect. Dis. 26, 2705-2708. https://doi.org/10.320 1/eid2611.203353

Bahl, P., de Silva, C., Bhattacharjee, S., Stone, H., Doolan, C., Chughtai, A.A., Maclntyre, C.R. (2020). Droplets and aerosols generated by singing and the risk of coronavirus disease 2019 for choirs. Clin. Infect. Dis. ciaa1241. https://doi.org/10.1093/cid/ciaa1241

Borchiellini, R., Fürbringer, J.M. (1999). Evaluation exercise of a multizone air flow model. Energy Build. 30, 35-51. https://doi.org/10.1016/S0378-7788(98)00045-0

Bourouiba, L., Dehandschoewercker, E., Bush, J.W.M. (2014). Violent expiratory events: on coughing and sneezing. J. Fluid Mech. 745, 537-563. https://doi.org/10.1017/jfm.2014.88

Buonanno, G., Stabile, L., Morawska, L. (2020). Estimation of airborne viral emission: Quanta emission rate of SARS-CoV-2 for infection risk assessment. Environ. Int. 141, 105794. https://doi.org/10.1016/j.envint.2020.105794

Chen, C., Zhao, B. (2011). Review of relationship between indoor and outdoor particles: I/O ratio, infiltration factor and penetration factor. Atmos. Environ. 45, 275-288. https://doi.org/10.10 16/j.atmosenv.2010.09.048

Chen, J., He, H., Cheng, W., Liu, Y., Sun, Z., Chai, C., Kong, Q., Sun, W., Zhang, J., Guo, S., Shi, X., Wang, J., Chen, E., Chen, Z. (2020). Potential transmission of SARS-CoV-2 on a flight from Singapore to Hanghzou, China: An epidemiological investigation. Travel Med. Infect. Dis. 36, 101816. https://doi.org/10.1016/j.tmaid.2020.101816

Cherrie, J.W., MacCalman, L., Fransman, W., Tielemans, E., Tischer, M., Van Tongeren, M. (2011). Revisiting the effect of room size and general ventilation on the relationship between nearand far-field air concentrations. Ann. Occup. Hyg. 55, 1006-1015. https://doi.org/10.1093/ann hyg/mer092

Cherrie, J.W., Fransman, W., Heussen, G.A.H., Koppisch, D., Jensen, K.A. (2020). Exposure Models for REACH and Occupational Safety and Health Regulations. Int. J. Environ. Res. Public Health 17, 383. https://doi.org/10.3390/ijerph17020383

Chua, R.L., Lukassen, S., Trump, S., Hennig, B.P., Wendisch, D., Pott, F., Debnath, O., Thürmann, L., Kurth, F., Völker, M.T., Kazmierski, J., Timmermann, B., Twardziok, S., Schneider, S., Machleidt, F., Müller-Redetzky, H., Maier, M., Krannich, A., Schmidt, S., Balzer, F., et al. (2020). COVID-19 severity correlates with airway epithelium-immune cell interactions identified by single-cell analysis. Nat. Biotechnol. 38, 970-979. https://doi.org/10.1038/s41587-020-0602-4

Dhaniyala, S., Dubey, P., Balakrishnan, K. (2011). Air quality in rural India: The role of ultrafine particles from cookstoves. Environmental Manager, Magazine of American Waste and Air Association, 2011, 14-18.

Duguid, J.P. (1946). The size and the duration of air-carriage of respiratory droplets and dropletnuclei. J. Hyg. (Lond). 44, 471-479. https://doi.org/10.1017/S0022172400019288

Feng, Y., Marchal, T., Sperry, T., Yi, H. (2020). Influence of wind and relative humidity on the social distancing effectiveness to prevent COVID-19 airborne transmission: A numerical study. J. Aerosol Sci. 147, 105585. https://doi.org/10.1016/j.jaerosci.2020.105585

Fernandez, M.O., Thomas, R.J., Garton, N.J., Hudson, A., Haddrell, A., Reid, J.P. (2019). Assessing the airborne survival of bacteria in populations of aerosol droplets with a novel technology. J. R. Soc. Interface. 16, 20180779. https://doi.org/10.1098/rsif.2018.0779

Feustel, H.E. (1999). COMIS-an international multizone air-flow and contaminant transport model. Energy Build. 30, 3-18. https://doi.org/10.1016/S0378-7788(98)00043-7

Freedman, D.O., Wilder-Smith, A. (2020). In-flight transmission of SARS-CoV-2: A review of the attack rates and available data on the efficacy of face masks. J. Travel Med. 27, taaa178. https://doi.org/10.1093/jtm/taaa178 
Gadgil, A.J., Lobscheid, C., Abadie, M.O., Finlayson, E.U. (2003). Indoor pollutant mixing time in an isothermal closed room: an investigation using CFD. Atmos. Environ. 37, 5577-5586. https://doi.org/10.1016/j.atmosenv.2003.09.032

Haas, A., Weber, A., Dorer, V., Keilholz, W., Pelletret, R. (2002). COMIS v3.1 simulation environment for multizone air flow and pollutant transport modelling. Energy Build. 34, 873882. https://doi.org/10.1016/S0378-7788(02)00062-2

Hussein, T., Korhonen, H., Herrmann, E., Hämeri, K., Lehtinen, K.E.J., Kulmala, M. (2005). Emission rates due to indoor activities: Indoor aerosol model development, evaluation, and applications. Aerosol Sci. Technol. 39, 1111-1127. https://doi.org/10.1080/02786820500421513

Hussein, T., Glytsos, T., Ondráček, J., Dohányosová, P., Ždímal, V., Hämeri, K., Lazaridis, M., Smolík, J., Kulmala, M. (2006). Particle size characterization and emission rates during indoor activities in a house. Atmos. Environ. 40, 4285-4307. https://doi.org/10.1016/j.atmosenv.200 6.03 .053

Hussein, T., Hruška, A., Dohányosová, P., Džumbová, L., Hemerka, J., Kulmala, M., Smolík, J. (2009a). Deposition rates on smooth surfaces and coagulation of aerosol particles inside a test chamber. Atmos. Environ. 43, 905-914. https://doi.org/10.1016/j.atmosenv.2008.10.059

Hussein, T., Kubincová, L., Džumbová, L., Hruška, A., Dohányosová, P., Hemerka, J., Smolík, J. (2009b). Deposition of aerosol particles on rough surfaces inside a test chamber. Build. Environ. 44, 2056-2063. https://doi.org/10.1016/j.buildenv.2009.02.009

Hussein, T., Kulmala, M. (2010). Micro-environmental Modelling, in: Lazaridis, M., Colbeck, I. (Eds.), Human Exposure to Pollutants via Dermal Absorption and Inhalation, Springer Netherlands, Dordrecht, pp. 251-277. https://doi.org/10.1007/978-90-481-8663-1_8

Jacobson, M.Z., Turco, R.P., Jensen, E.J., Toon, O.B. (1994). Modeling coagulation among particles of different composition and size. Atmos. Environ. 28, 1327-1338. https://doi.org/10.1016/13 52-2310(94)90280-1

Jamriska, M., Morawska, L., Ensor, D.S. (2003). Control strategies for sub-micrometer particles indoors: Model study of air filtration and ventilation: Control strategies for sub-micrometer particles indoors. Indoor Air 13, 96-105. https://doi.org/10.1034/j.1600-0668.2003.00184.x

Jayjock, M.A., Armstrong, T., Taylor, M. (2011). The Daubert standard as applied to exposure assessment modeling using the two-zone (NF/FF) model estimation of indoor air breathing zone concentration as an example. J. Occup. Environ. Hyg. 8, D114-D122. https://doi.org/10.1 080/15459624.2011.624387

Jensen, A., Dal Maso, M., Koivisto, A., Belut, E., Meyer-Plath, A., Van Tongeren, M., Sánchez Jiménez, A., Tuinman, I., Domat, M., Toftum, J., Koponen, I. (2018). Comparison of Geometrical Layouts for a Multi-Box Aerosol Model from a Single-Chamber Dispersion Study. Environments 5, 52. https://doi.org/10.3390/environments5050052

Johnson, G.R., Morawska, L., Ristovski, Z.D., Hargreaves, M., Mengersen, K., Chao, C.Y.H., Wan, M.P., Li, Y., Xie, X., Katoshevski, D., Corbett, S. (2011). Modality of human expired aerosol size distributions. J. Aerosol Sci. 42, 839-851. https://doi.org/10.1016/j.jaerosci.2011.07.009

Kim, Y.P., Seinfeld, J.H. (1992). Simulation of multicomponent aerosol dynamics. Journal of Colloid Interface Sci. 149, 425-449. https://doi.org/10.1016/0021-9797(92)90432-L

Koivisto, A.J., Jensen, A.C.Ø., Levin, M., Kling, K.I., Maso, M.D., Nielsen, S.H., Jensen, K.A., Koponen, I.K. (2015). Testing the near field/far field model performance for prediction of particulate matter emissions in a paint factory. Environ. Sci. Process. Impacts 17, 62-73. https://doi.org/10.1039/c4em00532e

Lai, A.C.K. (2004). Modeling of airborne particle exposure and effectiveness of engineering control strategies. Build. Environ. 39, 599-610. https://doi.org/10.1016/j.buildenv.2003.12.005

Lai, A.C.K., Nazaroff, W.W. (2000). Modeling indoor particle deposition from turbulent flow onto smooth surfaces. J. Aerosol Sci. 31, 463-476. https://doi.org/10.1016/S0021-8502(99)00536-4

Lindsley, W.G., Blachere, F.M., Thewlis, R.E., Vishnu, A., Davis, K.A., Cao, G., Palmer, J.E., Clark, K.E., Fisher, M.A., Khakoo, R., Beezhold, D.H. (2010). Measurements of airborne influenza virus in aerosol particles from human coughs. PLoS ONE 5, e15100. https://doi.org/10.1371/journal. pone.0015100

Lindsley, W.G., Pearce, T.A., Hudnall, J.B., Davis, K.A., Davis, S.M., Fisher, M.A., Khakoo, R., Palmer, J.E., Clark, K.E., Celik, I., Coffey, C.C., Blachere, F.M., Beezhold, D.H. (2012). Quantity and size distribution of cough-generated aerosol particles produced by influenza patients 
during and after illness. J. Occup. Environ. Hyg. 9, 443-449. https://doi.org/10.1080/1545962 4.2012.684582

Liu, L., Wei, J., Li, Y., Ooi, A. (2017). Evaporation and dispersion of respiratory droplets from coughing. Indoor Air 27, 179-190. https://doi.org/10.1111/ina.12297

Liu, Y., Yan, L.M., Wan, L., Xiang, T.X., Le, A., Liu, J.M., Peiris, M., Poon, L.L.M., Zhang, W. (2020a). Viral dynamics in mild and severe cases of COVID-19. Lancet Infect. Dis. 20, 656-657. https://doi.org/10.1016/S1473-3099(20)30232-2

Liu, Y., Ning, Z., Chen, Y., Guo, M., Liu, Yingle, Gali, N.K., Sun, L., Duan, Y., Cai, J., Westerdahl, D., Liu, X., Xu, K., Ho, K., Kan, H., Fu, Q., Lan, K. (2020b). Aerodynamic analysis of SARS-CoV-2 in two Wuhan hospitals. Nature 582, 557-560. https://doi.org/10.1038/s41586-020-2271-3

Loudon, R.G., Roberts, R.M. (1967). Droplet expulsion from the respiratory tract. Am. Rev. Respir. Dis. 95, 435-442. https://doi.org/10.1164/arrd.1967.95.3.435

Lu, J., Gu, J., Li, K., Xu, C., Su, W., Lai, Z., Zhou, D., Yu, C., Xu, B., Yang, Z. (2020). COVID-19 outbreak associated with air conditioning in restaurant, Guangzhou, China, 2020. Emerg. Infect. Dis. 26, 1628-1631. https://doi.org/10.3201/eid2607.200764

McDonald, J.E. (1964). The Mechanics of Aerosols. N. A. Fuchs. Translated from the Russian edition (Moscow) by R. E. Daisley and Marina Fuchs. C. N. Davies, Ed. Pergamon, London; Macmillan, New York, 1964. xiv + 408 pp. Illus. \$17.50. Science 146, 1033-1034. https://doi.org/10.1126/science.146.3647.1033-b

Miller, S. (2001). Environmental tobacco smoke particles in multizone indoor environments. Atmos. Environ.35, 2053-2067. https://doi.org/10.1016/S1352-2310(00)00506-9

Miller, S.L., Nazaroff, W.W., Jimenez, J.L., Boerstra, A., Buonanno, G., Dancer, S.J., Kurnitski, J., Marr, L.C., Morawska, L., Noakes, C. (2021). Transmission of SARS-CoV-2 by inhalation of respiratory aerosol in the Skagit Valley Chorale superspreading event. Indoor Air 31, 314-323. https://doi.org/10.1111/ina.12751

Morawska, L., Cao, J. (2020). Airborne transmission of SARS-CoV-2: The world should face the reality. Environ. Int. 139, 105730. https://doi.org/10.1016/j.envint.2020.105730

Morawska, L., Johnson, G.R., Ristovski, Z.D., Hargreaves, M., Mengersen, K., Corbett, S., Chao, C.Y.H., Li, Y., Katoshevski, D. (2009). Size distribution and sites of origin of droplets expelled from the human respiratory tract during expiratory activities. J. Aerosol Sci. 40, 256-269. https://doi.org/10.1016/j.jaerosci.2008.11.002

Morawska, L., Milton, D.K. (2020). It Is Time to Address Airborne Transmission of Coronavirus Disease 2019 (COVID-19). Clin. Infect. Dis. ciaa939. https://doi.org/10.1093/cid/ciaa939

Mosley, R.B., Greenwell, D.J., Sparks, L.E., Guo, Z., Tucker, W.G., Fortmann, R., Whitfield, C. (2001). Penetration of ambient fine particles into the indoor environment. Aerosol Sci. Technol.34, 127-136. https://doi.org/10.1080/02786820117449

Nazaroff, W.W., Cass, G.R. (1986). Mathematical modeling of chemically reactive pollutants in indoor air. Environ. Sci. Technol. 20, 924-934. https://doi.org/10.1021/es00151a012

Nazaroff, W.W., Cass, G.R. (1989). Mathematical modeling of indoor aerosol dynamics. Environ. Sci. Technol. 23, 157-166. https://doi.org/10.1021/es00179a003

Nicas, M., Nazaroff, W.W., Hubbard, A. (2005). Toward Understanding the Risk of Secondary Airborne Infection: Emission of Respirable Pathogens. J. Occup. Environ. Hyg. 2, 143-154. https://doi.org/10.1080/15459620590918466

Papineni, R.S., Rosenthal, F.S. (1997). The size distribution of droplets in the exhaled breath of healthy human subjects. J. Aerosol Med. 10, 105-116. https://doi.org/10.1089/jam.1997.10.105

Park, S.Y., Kim, Y.M., Yi, S., Lee, S., Na, B.J., Kim, C.B., Kim, J., Kim, H.S., Kim, Y.B., Park, Y., Huh, I.S., Kim, H.K., Yoon, H.J., Jang, H., Kim, K., Chang, Y., Kim, I., Lee, H., Gwack, J., Kim, S.S., et al. (2020). Coronavirus Disease Outbreak in Call Center, South Korea. Emerg. Infect. Dis. 26, 16661670. https://doi.org/10.3201/eid2608.201274

Ribalta, C., Koivisto, A.J., López-Lilao, A., Estupiñá, S., Minguillón, M.C., Monfort, E., Viana, M. (2019). Testing the performance of one and two box models as tools for risk assessment of particle exposure during packing of inorganic fertilizer. Sci. Total Environ. 650, 2423-2436. https://doi.org/10.1016/j.scitotenv.2018.09.379

Riley, W.J., McKone, T.E., Lai, A.C.K., Nazaroff, W.W. (2002). Indoor particulate matter of outdoor origin: Importance of size-dependent removal mechanisms. Environ. Sci. Technol. 36, 200207. https://doi.org/10.1021/es010723y 
Schneider, T., Kildes, J., Breum, N. o. (1999). A two compartment model for determining the contribution of sources, surface deposition and resuspension to air and surface dust concentration levels in occupied rooms. Build. Environ. 34, 583-595. https://doi.org/10.1016/ S0360-1323(98)00048-1

Shimada, M., Okuyama, K., Okazaki, S., Asai, T., Matsukura, M., Ishizu, Y. (1996). Numerical simulation and experiment on the transport of fine particles in a ventilated Room. Aerosol Sci. Technol. 25, 242-255. https://doi.org/10.1080/02786829608965394

Smolík, J., Lazaridis, M., Moravec, P., Schwarz, J., Zaripov, S.K., Ždímal, V. (2005). Indoor aerosol particle deposition in an empty office. Water Air Soil Pollut 165, 301-312. https://doi.org/10.1 007/s11270-005-7146-6

Stadnytskyi, V., Bax, C.E., Bax, A., Anfinrud, P. (2020). The airborne lifetime of small speech droplets and their potential importance in SARS-CoV-2 transmission. Proc. Natl. Acad. Sci. U.S.A. 117, 11875-11877. https://doi.org/10.1073/pnas.2006874117

Thornburg, J., Ensor, D.S., Rodes, C.E., Lawless, P.A., Sparks, L.E., Mosley, R.B. (2001). Penetration of particles into buildings and associated physical factors. Part I: Model development and computer simulations. Aerosol Sci. Technol. 34, 284-296. https://doi.org/10.1080/027868201 19886

van Doremalen, N., Bushmaker, T., Morris, D.H., Holbrook, M.G., Gamble, A., Williamson, B.N., Tamin, A., Harcourt, J.L., Thornburg, N.J., Gerber, S.I., Lloyd-Smith, J.O., de Wit, E., Munster, V.J. (2020). Aerosol and Surface Stability of SARS-CoV-2 as Compared with SARS-CoV-1. N. Engl. J. Med. 382, 1564-1567. https://doi.org/10.1056/NEJMc2004973

World Health Organization (WHO) (2020a). Novel Coronavirus - China. https://www.who. int/csr/don/12-january-2020-novel-coronavirus-china/en/ (accessed 12 January 2020).

World Health Organization (WHO) (2020b). Pneumonia of unknown cause - China. https://www.who.int/csr/don/05-january-2020-pneumonia-of-unkown-cause-china/en/ (accessed 5 January 2020).

World Health Organization (WHO) (2020c). Schools and other educational institutions transmission investigation protocol for coronavirus disease 2019 (COVID-19), 30 September 2020, version 1.1. World Health Organization. https://apps.who.int/iris/handle/10665/336253

Xie, X., Li, Y., Chwang, A.T.Y., Ho, P.L., Seto, W.H. (2007). How far droplets can move in indoor environments? revisiting the Wells evaporation-falling curve. Indoor Air 17, 211-225. https://doi.org/10.1111/j.1600-0668.2007.00469.x

Zhang, Y., Banerjee, S., Yang, R., Lungu, C., Ramachandran, G. (2009). Bayesian modeling of exposure and airflow using two-zone models. Ann. Occup. Hyg. 53, 409-424. https://doi.org/ 10.1093/annhyg/mep017 